\title{
An Application of Grice's Cooperative Principle to the Analysis of a Written Business Negotiation Model
}

\author{
R. Baghramyan \\ Armenian State University of Economics \\ Corresponding author. E-mail: rouzannabaghramyan@gmail.com
}

Paper received 10.03.21; Accepted for publication 03.04.21.

\section{https://doi.org/10.31174/SEND-HS2021-253IX45-02}

\begin{abstract}
This article focuses on institutional discourse pragmatics, highlighting its salient features in a business to customer negotiation model, based on an authentic business correspondence (email), through a prism of H. Grice's Theory of Cooperative Principle. The central thrust of this theory is the application of the maxims of Quantity, Quality, Relation and Manner to speech acts to secure identification of participants' intentions and sentence meaning, excluding irrelevancies throughout the communication process. Any kind of interaction in our life is accompanied by diverse tangible and intangible components. The role, function and impact of these aggregate components on the natural flow of communication irrespective of the form (oral/written) are the concern of pragmatics.
\end{abstract}

Keywords: discourse pragmatics, Gricean maxims, institutional discourse, business negotiations

Introduction. The multi-layered nature of discourse, its omnipresence in almost every sphere of human activity, allows us to study its diverse features in relation to other sciences. Scholars in linguistics, psycholinguistics and sociolinguistics recognized that the study of actual language use should not be limited to grammatical analysis of isolated sentences and advocated a focus on the structures, strategies and processes of the cognitively and socially situated text and talk of real language users [Van Dijk, 2009, p. 1]. Linguistic studies have extended their scope of research of the language, as one of the staples of human communication, to include cultural, social and cognitive dimensions. The study of discourse from the perspective of these dimensions is in the realm of pragmatics. As one of the disciplines of linguistic studies, pragmatics encompasses the whole gamut of contextual features providing an opportunity not only to analyze the written text or talk on the level of words or utterances, but also consider, interpret and examine all the factors contributing to the final result of the talk or text. Components, constituting pragmatics, create a platform throughout the communication process (written/spoken) to reach a certain outcome, which will be mutually acceptable or intend to share knowledge, which will become common for the parties involved in the communication process. On many occasions, the result is invisible at earlier stages, but it lays a foundation for further development. This is due to the indirect utterances, the meaning of which should be pragmatically inferred. The conventional pragmatic research is based on three pivotal pillars providing insights into the discourse pragmatic analysis. These are H. Grice's Theory of Cooperative principle, J. Austin and J. Searle's Speech Act Theory, P. Brown and S. Levinson's Model of Politeness.

Theory of Cooperative Principle (4 maxims). $\mathrm{H}$. Grice Theory of Cooperative Principle plays a seminal role in the formation of pragmatic research. In his book "Logic and Conversation" he introduces the concept of implicature. The inferred meaning of utterance is defined as implicature. Intentional communication assumes either explicit or implicit conveyance of the message. When one uses the conventional meaning of the word, they express their ideas explicitly. If one of the participants does not want to communicate the message explicitly, the other side should consider an array of factors relevant to the situation to infer the meaning. For instance, in the utterance 'This is a disaster' one may interpret the direct, conventional meaning of the word disaster - earthquake, hurricane or flooding. The consideration of multiple factors governing this utterance (physical setting, economic situation, familiarity with the context) significantly alter the perception of the sentence. A person observing a sharp decline in his share price may utter this phrase. When we deprive the sentence of the context and leave it with its conventional meaning, we do not leave space for extrapolation. H. Grice divides implicatures into conventional and non-conventional types. Conversation is regarded as a subclass of non-conventional implicature endowed with discourse attributes. He proposes 4 maxims under the Theory of Cooperative Principle to secure efficacious communication: 1 - Quantity, 2 - Quality, 3 - Relation, 4 - Manner.

1. Quantity - If you are assisting me to mend a car, I expect your contribution to be neither more nor less than is required; if I need four screws, I expect you to hand me four rather than two or six.

In other words, in business context, if the customer asks for a discount for a particular product, there is no need to send the price list for all discounted products.

2. Quality - I expect your contributions to be genuine and not spurious. If I need sugar as an ingredient in the cake, you are assisting me to make, I do not expect you to hand me salt; if I need a spoon, I do not need a trick spoon made of rubber.

'Honesty is the best policy'. By treating the interlocuter with probity and integrity, one establishes long-lasting, trustworthy relationship and pave the way to a desired result.

3. Relation- I expect a partner's contribution to be appropriate to the immediate needs at each stage of transaction; if I am mixing ingredients for a cake, I do not expect to be handed a good book, or even an oven cloth (though this might be an appropriate contribution at a later stage).

Adherence to relevancy of the components of discourse pragmatics in relation to the present situation is central to both written and spoken interactions. For example, if the customer requests information on the type of the materials used in the production process, there is no need to provide information about price or that the seller offers a $10 \%$ discount for paying in cash.

4. Manner - I expect a partner to make it clear what contribution he is making and to execute his performance 
with reasonable dispatch. [Grice, 1975, p. 47]

Thus, contributions must be implemented transparently and show good judgement. "Our talk exchanges do not normally consist of a succession of disconnected remarks, and would not be rational if they did" [Grice, 1975, p. 45]. All contributions serve a general objective, thereby require cooperative efforts to accomplish the task set from the outset. On the other hand, participants may "violate, opt out, flout" the maxims in a way they consider effective for their cooperation. On many occasions, interactants violate the maxim of Quantity to be more polite and keep their social face. This notion of 'face' is based on the theory of CanadianAmerican sociologist E. Goffman. According to his theory face is "the positive social value a person effectively claims for himself by the line others assume he has taken during a particular contact" [Goffman, 1967 as cited in BlumKulka, Hamo, 2019. p. 152]. This forms the basis P. Brown and S. Levinson's Model of Politeness. They premised their idea on the face-saving theory, claiming that face has two dimensions: positive and negative. The constant shifting from one face to the other is a natural phenomenon throughout the interaction. One cannot keep a positive face continuously. Indubitably, it is one of the prerogatives of a person to maintain a socially positive face, adhering to a certain set of socially accepted principles and values, however it may sometimes seem imposing. Communicators feel losing their autonomy and freedom. Hence, the application of the negative face is vital for keeping the balance. Y. Yerznkyan in her book "Linguistic Category of Politeness" states that "Theory of Linguistic Politeness is understood as a guarantee of conflict-free communication and polite speech behavior presupposes a line of behavior that maximally takes into account the desires, feelings and inclinations of the partner in communication" [Yerznkyan, 2018 , p. 67]. In essence, the theory of politeness executes the same function as the maxims: to reach a mutually accepted outcome with cooperative efforts. Mediums and linguistic tools are different and sometimes mutually exclusive, nevertheless the two theories are thoroughly intertwined. Likewise, J. Austin's Speech Act Theory, later developed by J. Searle, supplements the aforementioned theories, allowing us to research pragmatic field in a more systemized way. "A Speech Act is a purposeful speech action performed in accordance with the principles and rules of communicative behavior in each given society" [Yerznkyan, 2018, p. 28]. J. Austin distinguishes among locutionary (a meaningful utterance), illocutionary (the performance of the utterance) and perlocutionary (the effect the two acts have on the hearer) speech acts. Within one utterance, the communicator may perform all three acts. Based on J. Austin's work, J. Searle suggests 5 types of illocutionary acts:

1. Representatives: utterances that describe some state of affairs by asserting, concluding, claiming, etc.

2. Directives: utterances used to get hearer to do something via acts like ordering, commanding, begging, requesting and asking.

3. Commissives: utterances that commit hearer to doing something and include acts like promising, vowing and pledging alliance.

4. Expressives: acts used to express the psychological state of the hearer, by thanking, apologizing, congratulating and condoling.
5. Declarations: utterances which effect a change in some, often institutionalized state of affairs. Paradigm examples are christening a baby, declaring peace, firing an employee. [Searle, 1979]

This classification has been disputed by many critics and yet it is certain that it provides a solid ground for further development of the field and additional deliberation.

Institutional Discourse/Non-Institutional Discourse (Personality-oriented and Status-oriented Communication). Russian linguist V. Karasik in his work "Language circle; person, concepts, discourse" distinguishes between personality-oriented and status-oriented types of communication. Status-oriented communication is typical of institutional discourse: negotiations, interviews, meetings, court trials, etc. "The norms of institutional discourse reflect the ethnic values of the society as a whole and the values of a particular social group that forms the institution" [Karasik, 2002, p. 196]. With the advent of modern technologies, the modes of institutional discourse have changed. For example, business to customer (or any other type of communication) interaction can no longer be restricted to a designated physical institutional setting, since business deals/transactions can be negotiated from home, via email, video conferencing, etc. Moreover, smart phones provide an opportunity to send emails from almost all places with WIFI connection. Subsequently, the Internet has become one of the indispensable tools of interaction. In personality-oriented communication the interlocuter may expand beyond natural phrases, words, deviate from the topic and communicate some personal information, which may not contribute to the fulfilment the objectives of the interaction. On the contrary, participants in the status-oriented interaction avail themselves of all the tools available to influence the other party to gain an advantage. They use clichéd phrases, exchange accepted formal pleasantries, avoiding, at the same time, any personal interference. This would be much easier to implement if artificial intelligence was used in status-oriented communications. Unlike artificial intelligence, which is programmed in advance to perform a certain type of activity, people are rather sensitive to certain situations, topics, therefore the borderline between the status-oriented and personality-oriented communication can be easily crossed, sometimes intentionally. J. Nierenberg in his work "Art of Negotiating" indicates that people negotiate each time when they exchange ideas with the intention to reach an agreement. [Nierenberg, as cited in Введенская, Павлова, 2019, p. 97]. This intentional, purposeful feature distinguishes negotiations from ordinary talk. Negotiations are classified according to the sphere of activity: diplomatic, political, economic, trade, business, etc., according to the purpose: to sign an agreement, to extend existing agreement, to make amendments in contracts/treaties, etc. and according to the nature of the relationship between the parties: partnerships, competitive, confrontational [Введенская, Павлова, 2019, p. 97-98]. The most common types of negotiation are integrative, when parties collaborate to reach a mutually beneficial 'win-win' solution and distributive, based on win-lose strategy. In business negotiations, the parties usually avoid the win-lose outcome. As J. Nirenberg states the aim of negotiations is not a 'dead' or 'crushed' opponent [Nierenberg, as cited in Введинская, Павлова, 2019]. The main 
thing in negotiations is not the assertion of one's own position, but the satisfaction of mutual interests. In this respect, the value-based negotiation model (VBM) suggests 4 elements to consider before and during negotiations: the negotiator's values, what he needs from the other party, how he builds the desired relationship and how he appeals to the other party's goodness staying true to his values [Gan, 2017]. Whilst priming yourself for negotiations one should ponder over these elements to secure the most acceptable, mutually beneficial solution for both parties. The two staples of VBM are emotions and feelings, which are intangible means of expressing personal attitudes. To succeed in negotiations, the negotiators should target the feelings of the other party rather than the emotions, which are usually evoked due to external factors, whereas feelings are embedded in our conscious and have a significant impact on the decision-making process. For instance, when the seller refuses to reduce the price reasoning that $5 \%$ of the profit will be donated to the "Foundation for Serviceman" to pay compensation to the families of soldiers who fell defending their homeland, he arouses such feelings as patriotism, a sense of duty to those soldiers, compassion. As a result, the purchaser immediately stops bargaining. It is not the temporary emotion that may be caused even by watching a movie, but the deep feeling of love for one's homeland that helps to achieve a win-win situation in this specific context. The same approach is viable in written interactions. Consequently, during the process of institutional interaction the interplay among the several types of communication is natural. Interaction may be shifted from spoken to written and vice versa. Written forms of conveying information or accomplishing practical tasks within the scope of status-oriented communication comprises emails, letters, documents, text messaging, etc. Each mode of language used in institutional context (written/spoken) requires the application of established standards and norms typical of that form. Formal correspondence is usually done by letters/emails, which leave a written record and can be kept for future reference. There are certain conventions to follow while using a written form of communication: layout, register, style, spelling, etc. For example, in a job application form, it is important to put a job title after the name of the person you are writing to. Formal letters always start with 'Dear' and end with 'Yours Sincerely', if one knows the name of the recipient, or 'Yours Faithfully' if you do not know the name of the recipient (for less formal letters Best regards, Best wishes). Let us consider the business correspondence below, which illustrates a written interaction between a business and a potential customer bargaining over a product (carpet) price and analyze it applying the maxims discussed above. The examples are taken from "Tufenkian Carpets" LTD operating in Armenia. Bargaining parties are native speakers of English and no changes have been made to the emails.

Example 1. Dear Ms. X,

Following our visit to your shop and as agreed I am sending you attached a photo of a carpet, which we want to order. The US size we want is: 6' x 9' $(1.84 \mathrm{~cm} \times 2.73 \mathrm{~cm})$.

Please kindly let me know how much will be the price and when the carpet will be ready. Thank you.

Best regards,

Y

Example 2. Dear Mrs Y,
The price of this TK $1325 \times 25$ density $1.84 \times 2.73=5.02 \mathrm{sqm}$ rug is the following: $5.02 \mathrm{sqm} \times 134010$ (1 $\mathrm{sqm}$ price) drams = 672700 drams. And the whole producing process will be about 2.5 - 3 months, starting from your final confirmation day. Please let me know if any questions.

Best regards, $\mathrm{X}$

Example 3. Dear X,

Will you give me a discount for this carpet since I am a regular client of your shop? Thanks.

Best,

Y

Example 4. Dear Y,

Taking into consideration that you are our regular customer and according to Arman Grigoryan's instructions the price that I gave for the rug is already with rather big discount (with about 40 000 AMD for per sgm - total 200000 AMD), as the regular price for this is 170000 per sqm. So, I am sorry, but we cannot do any more discount and $672700 \mathrm{AMD}$ is the minimal price.

best regardrs, $\mathrm{X}$

Example 5. Dear Mr. X,

Thank you for your response and the clarification provided. I agree with the price offered by you and would like to order the carpet. Please consider this e-mail as a confirmation for the purchase. I will be traveling on mission abroad and will be back in Yerevan on $7^{\text {th }}$ July when I can pay an advance for the order. Let me know if this is OK with you. Thank you.

Best,

Y

Firstly, this is a typical example of institutional discourse (written business communication), hence it embodies formal features of scripted interaction. In all 5 emails the accepted cliched forms of email openings and closings are used; dear, best, best regards. These formalities have become inseparable part of written communication. There is no need even to type these words, they appear mechanically on the screen. Such hackneyed style can no longer serve as a gesture of politeness or have an impact on the reader's attitude or influence the decision-making process. Judging from the above emails the participants realize the negligible effect of the 'polite' extra phrases, consequently they do not make any efforts to be more polite than necessary. By doing this, they are managing their time in a more effective way. Time management is considered to be one of the fundamental skills in a business negotiation process. In this particular correspondence, parties seem to have applied the Pareto Principle ( $80 / 20$ rule), which states that $80 \%$ of the result comes from $20 \%$ of the effort. Minimizing efforts (using less words) can be equal to the maxim of Quantity, which is compensated through applying a maxim of Quality. Make your conversational contributions such as is required, at the stage at which it occurs, by the accepted purpose or direction of the talk exchange in which you are engaged [Grice,1975]. The application of maxims is obvious, without any noticeable infringement. It is apparent that participants know each other, therefore they use less formal language (email 3; best). The standard institutional setting is vague, since in written communication an array of settings is suitable (home, workplace, restaurant, cafes, cars). Most probably they have been writing these emails on their way home, work, or while having lunch, as a result some spelling (best regards, sgm, email 4) mistakes are observable. The interactions are brief and to the point (maxim of Quantity and Relation). The emails provide illocutionary 
acts that use performative verbs in conjunction with appropriate conditions to accomplish certain actions. According to J. Searle's classification, these are directives (email 3 requesting act), expressives (email 4, apologizing act) declarations (email 4, refusing act).

Let us consider email 3 where the phrase 'regular client' is a relevant and genuine contribution (maxims of Quality and relevance) made by the client which is mutually acceptable. The contributions are comprehensible and direct without any obscure implications (maxim of Manner). No false information is provided or any circumvention of the generally accepted norms (maxim of Quality).

In example 4 , the seller expands beyond the requested information about the discount, and mentions the name of the manager to display the extent of care she treats her client and also mentions that they have already given a discounted price. One may consider that the maxim of Quantity is flouted in this sentence. However, given the fact that Mrs. Y is a regular customer (she knows Mr. Grigoryan) and the relationship between them is more friendly than formal, the provided information can be perceived as a cooperative effort towards a common goal. When the phrase is not separated from the context, but is interpreted taking into account all the factors influencing the course of interaction, i.e. pragmatic components, then it becomes obvious that the attributes of cooperative principle are maintained. H. Grice claims that alleged irrelevancies may seem to ex- ist due to the ignorance of contributing factors and conditions guiding communication. Conversely, written communication does not provide much space for the supposed divergency, since it is mostly confined to the application of linguistic elements pertaining to the standards of written correspondence. Neither side in this negotiation wants to gain advantage over the other party, trying to reach winwin solution. To guide the discourse to the direction that benefits you and do not upset the customer is easier to implement in written communication. Written speech is graphically fixed, it can be considered and corrected in advance, it has some linguistic features (literary vocabulary, complex prepositions, passive constructions, strict adherence to linguistic norms, absence of extra-linguistic elements) [Введенская, Павлова, 2019, p. 167].

Conclusion. To conclude, it should be restated that the all-pervasiveness of pragmatic features in our life is an incontrovertible fact and its components intrinsically relate to not only discourse of everyday life but to institutional discourse in its various manifestations. By employing pragmatic components accompanied by the consideration of the reciprocity of standpoints and application of maxims provide basis to produce and develop coherent institutional business discourse in a written form and achieve a mutually beneficial result. Gricean maxims are viable in business negotiations, since the application of these maxims saves the most precious asset - time, by excluding any deviations from the collective goal.

\section{LITERATURE}

1. Austin J.L. (1962). How to do Thing with words, Oxford University Press

2. Gan I. (2017). Advancing a Distributive-Bargaining and Integrative-Negotiation Integral System: A Values-Based Negotiation Model (VBM)//Social Sciences, 2017, 6, (115) Is. 3.

3. Grice H.P. (1975). Logic and Conversation, Elsevier

4. Карасик В.И. (2002). Языковой круг: личность, концепты,

дискурс, ВГПУ, издательство «Перемена»

5. Введенская Л.А., Павлова Л.Г. (2019). Деловая Риторика, издательство «КноРус»

6. Van Dijk Teun A. (2009). Discourse Studies; a Multidisciplinary Introduction, Sage Publications LTD

7. Ерзнкян Е. Л. (2018). Лингвистическая Категория Вежлижости, издательство ЕГУ

\section{REFERENCES}

1. Austin J.L. (1962). How to do Thing with words, Oxford University Press

2. Gan I. (2017). Advancing a Distributive-Bargaining and Integrative-Negotiation Integral System: A Values-Based Negotiation Model (VBM)//Social Sciences, 2017, 6, (115) Is. 3.

3. Grice H.P. (1975). Logic and Conversation, Elsevier

4. Karasik V.I. (2002). Language circle: person concepts, discourse, VSPU, 'Peremena' publishing house

5. Vvedenskaya L.A., Pavlova L.G. (2019). Business Rhetorics, 'KnoRus' publishing house

6. Van Dijk Teun A. (2009). Discourse Studies; a Multidisciplinary Introduction, Sage Publications LTD

7. Yerznkyan Y. L. (2018). Linguistic Category of Politeness, YSU publishing house 